\title{
Re-formulation zakat system as tax reduction in Indonesia
}

\author{
Hary Djatmiko
}

The Supreme Court of the Republic of Indonesia

E-mail:harydj@gmail.com

DOI: $10.18326 /$ ijims.v9i1.135-162

\begin{abstract}
Zakat is one of the Islamic financial instruments which is obligatory for every Muslim whose earnings reach the prescribed amount (nishab). On the other hand taxes must still be paid as an obligation of every citizen. Under the law, it is stated that zakat can be a deduction from taxable income. The aim of this research is to offer a more advanced concept, namely zakat can be a deduction from income tax. The technique used in this research is content analysis on the literatures discussing about zakat and tax in Islam. The results of this study suggest that zakat as a deduction from income tax has a greater impact than zakat as merely a deduction from taxable income. Zakat as a deduction from income tax will increase the impact of zakat in a larger economy.
\end{abstract}

Zakat merupakan salah satu instrument keuangan Islam yang wajib ditunaikan oleh setiap umat muslim yang pendapatannya telah memenuhi jumlah yang ditentukan (nisab). Sedangkan, di sisi lain pajak harus tetap dibayarkan sebagai suatu kewajiban dari setiap warga Negara. Berdasarkan undang-undang, disebutkan bahwa zakat dapat menjadi pengurang penghasilan kena pajak. Tujuan penelitian ini ialah untuk menawarkan suatu suatu konsep yang lebih maju yaitu zakat dapat sebagai pengurang pajak penghasilan. Teknik analisis yang digunakan ialah analisis isi terhadap literatur-literatur terkait zakat dan pajak dalam Islam. Hasil penelitian menunjukkan bahwa zakat sebagai 
pengurang pajak penghasilan memiliki dampak lebih besar daripada jika zakat hanya sebagai pengurang penghasilan kena pajak. Zakat sebagai pengurang pajak penghasilan akan meningkatkan dampak zakat di dalam perekonomian yang lebih besar.

Keywords: Zakat; Tax; Tax reduction; Economic welfare

\section{Introduction}

Zakat is one of the obligations that must be carried out by every Muslim who has fulfilled the requirements. ${ }^{1}$ Zakat is one of the Islamic pillars and as old as Islamic civilization. ${ }^{2}$ Zakat has socio-economic-spiritual dimensions, which crates economic balance for the people welfare. ${ }^{3}$ The purpose of zakat utilization is basically anything that provides benefits to the entire community, including efforts which lead to the benefits of the people. The goals of zakat distribution are to decrease inequality, to establish human rights, to remove social injustice and to bring empowerment of the poor people of the Muslim society. ${ }^{4}$ Zakat is the manifestation of social solidarity, the form of humanity and fairness senses, inner binder between rich and poor people, as well as wiper of the gap between rich and poor people. ${ }^{5}$

${ }^{1}$ Rose Abdullah and Abdurrahman Raden Aji Haqqi, "Zakah for Asnaf Al-Gharimun in Brunei Darussalam: Concepts and Pratices", Al-lqtishad: Jurnal Ilmu Ekonomi Syariah, Vol. 9, Number 2 (July 2017), 244.

2 Dian Masyita, "Lessons Learned of Zakah Management from Different Era and Countries", Al-lqtishad: Jurnal Ilmu Ekonomi Syariah, Vol. 10, Number 2 (July 2018), 442.

${ }^{3}$ Kumara Adji Kusuma and Muhamad Nafik Hadi Ryandono, "Zakah Index: Islamic Economics' Welfare Measurement”, Indonesian Journal of Islam and Muslim Societies, Vol. 6, Number 2 (2016), 274.

4 Abdulah Al-Mamun and Ahasanul Haque, "Tax Deduction Through Zakat: An Empirical Investigation on Muslim in Malaysia”, Share, Volume 4, Number 2 (July-December 2015), 107.

${ }^{5}$ Indra Pahala, "Zakat is More Significant Than Tax". Review of Integrative Business and Economic Research, Volume 5, Number 2 (2016), 286. 
Indonesia is the largest Muslim country in the world with more than 220 million Muslims (almost 88\%) out of the 240 million populations. This percentage has shown how big the potential for zakat collection is. Nevertheless, the realization of zakat collection is still far from its potential. In 2015, the potential of zakat funds in Indonesia would be about IDR 82 trillion, however, the realization of revenues was only IDR 74 billion $^{6}$. Another study has revealed that the zakat funds collected were only $1.7 \%$ of the potential zakat per year. ${ }^{7}$

Several factors may cause the ineffectiveness of zakat management in Indonesia both in terms of collection and empowerment. First, there is still a low level of public understanding of zakat. Second, the level of the community trust to the amil zakat institution has not been fully developed properly. This is proven by the number of muzaki who prefers to pay their zakat directly to mustahiq (recipient) rather than to the amil. Third, the management of zakat by amil has not been fully implemented based on good management principles. ${ }^{8}$

Furthermore, the gap between potential and realization was also caused by the emergence of two double obligations, namely tax and zakat. This condition has brought people's reluctance to pay zakat in Indonesia. An attempt has been made To increase the number of zakat payers, an attempt has been made by giving an incentive, in this instance, permitting zakat to be a taxable income deduction. Zakat as a compulsory obligation, is payable for the Muslim whose earnings have attained the

\footnotetext{
${ }^{6}$ Clarashinta Canggih, Khusnul Fikriyah, and Ach. Yasin, “ Potensi dan Realisasi Dana Zakat di Indonesia”, Al-Uqud: Journal of Islamic Economics, Vol. 1, Number 1 (January 2017), 20-21.

${ }^{7}$ Moh Abdur Rohman Wahid, "Integrasi Pajak dan Zakat di Indonesia Perspektif Hukum Islam dan Hukum Positif", El-Jizya: Jurnal Ekonomi Islam, Volume 4, Number 1 (January-June 2016), 31.

${ }^{8}$ Sodiman, Mustafa, Hadi, Muhammad, Ahmadi, and L. Hadisi, "Potensi dan Efketivitas Pengelolaan Zakat di Kabupaten Konawe Selatan”, Li Falah: Jurnal Studi Ekonomi dan Bisnis Islam, Volume I, No. 2 (December 2016), 70.
} 
minimum zakatable amount called nishab in Islamic jurisprudence. ${ }^{9}$

The Indonesian government also has imposed the obligation to pay taxes to all citizens. ${ }^{10}$ Discourse on taxes, especially in Islamic countries has become something that is often debated. The tax collected is an income source from the government to funding its administrative and development of the country. ${ }^{11}$ In general, the utilization of zakat aims to provide maslahah for the people. The well managed zakat funds will have an impact on economic growth. In a conventional economic textbook, this concept is known as the concept of economic growth with equity.

Eventhough scholars (Ulama) have agreed that taxes are not a recognized system of levies in Islam, some of them allow voluntary taxes. ${ }^{12}$ The scholars justifies the difficulties burdened by Muslims because of the dualism of zakat and taxes. However, this justification is in accordance with sharia provisions and will guarantee the sustainability of these obligations and perpetuate relations between Muslims through zakat. Therefore, zakat cannot be removed and replaced by taxes; and taxes also cannot disappeared. ${ }^{13}$

The presence of the Zakat Act (The Act No. 38/1999 and The Act No. 23/2011) and also the Tax Act (The Act No. 17/2000) have shown the seriousness of the government to create the implementation of its religious obligations by making the element of zakat to be one of the tax reliefs in collecting income tax $(\mathrm{PPh})$ in Indonesia. At present the act

${ }^{9}$ Lukman Raimi, Ashor Patel, and Ismail Adelopo, "Corporate Social Responsibility, Waqf System, and Zakat System as Faith-based Model for Poverty Reduction”, World Journal of Entrepreneurship, Management and Sustainaible Development, Volume. 10, Issue 3 (2014), 229.

${ }^{10}$ Dian Masyita, "Lessons Learned of Zakah Management"..., 448.

${ }^{11}$ Rohila Awang and Mohd Zulkifli Mokhtar, "Technical Comparison Between Business Zakat and Tax on Business Income in Malaysia”, Malaysian Accounting Review, Volume 10, Number 2 (2011), 15.

${ }^{12}$ M Nur Rianto Al Arif, "Fungsionalisasi Zakat dan Pajak di dalam Perekonomian”, Jurnal Ekonomi Islam, Volume 3, Number 1 (April 2013), 43.

${ }^{13}$ Moh Abdur Rohman Wahid, "Integrasi Pajak dan Zakat di Indonesia"..., 48. 
makes zakat to be one of the deducting factors for the personal income of the personal taxpayer (WPOP) in determining the amount of taxable income. ${ }^{14}$ For muslim taxpayer, the zakat rebate is an opportunity to avoid paying income tax or reduce income tax contribution ${ }^{15}$. However, public interest in utilizing zakat as a deduction from taxable income is still low. ${ }^{16}$ This arises is because of the community feeling that this zakattax incentive is still less attractive. The community considers the burden of paying taxes and zakat is still too large. This is the reason why the rules regarding zakat as a deduction from taxable income need to be revised.

This paper presents an analytical discussion on the re-formulation of zakat system as tax reduction in Indonesia which gives a significant contribution for the zakat literature in Indonesia. In addition, the results of this research adds a significant contribution for the policymakers in re-formulation the zakat system as a tax reduction.

\section{Zakat and its impact on economy}

Zakat is the third from the five pillars of Islamic faith. Zakat is a manifestation of the obedience of the ummah to the commands of Allah SWT. ${ }^{17}$ Zakat is one of the fiscal instruments in the economy that has been used by Islamic governments since the Prophet Muhammad. Based on the history, zakat has played an important role in the mechanism of income distribution in the economy. Proper, professional and accountable management of zakat will have a significant influence on the economy.

\footnotetext{
${ }^{14}$ Murtadho Ridwan, "Zakat vs Pajak: Studi Perbandingan di Beberapa Negara Muslim”, Ziswaf, Volume 1, Number 1 (June 2014), 148.

${ }^{15}$ Puteri Nur Liana, "A Preliminary Study o Norms and Motivations Towards Zakat and Income Tax Payment by Muslim Tax Payer", International Academic Journal of Accounting and Financial Management. Volume 5, Number 3 (2018), 118.

${ }^{16}$ Siti Umus Salamah, "Relasi Zakat dan Pajak: Studi Kasus Badan Amil Zakat Nasional Kabupaten Malang dan Kantor Pelayanan Pajak Pratama Kepanjen Malang”, Jurisdictie: Jurnal Hukum dan Syariah, Volume 6, Number 1 (2015), 26.

${ }^{17}$ Murtadho Ridwan, "Zakat vs Pajak"..., 126.
} 
The obligation of a Muslim to pay zakat is regulated in the Quran. One of the verses governing the obligation of zakat is the Quran Surah al-Tawbah verse 10: "Take zakat from some of their property, with that zakat you cleanse and purify them and pray for them. Verily your prayer will be for them. and Allah is Hearer, Knower".

The word "cleanse" in this verse means that zakat is able to cleanse the hearts of the Muslims from the miserly nature and excessive love for property. Whereas the word "purify" means that zakat can enrich the qualities of virtue in the hearts of the Muslims ${ }^{18}$.

There are many histories in the hadith that explains about the obligation of zakat including the hadith narrated by Bukhari and Muslim from Abdullah bin Umar "Islam is built on five pillars: Creed is Godless except Allah and Muhammad the messenger of Allah, establishes prayer, pays zakat, performs the Hajj and fasting of Ramadan.” [Bukhari Muslim].

Zakat in general can be defined as part of the assets that must be paid by every Muslim believer who has fulfilled certain conditions based on Shari'a rules and guidelines. The Law No. 23 of 2011 article 1 paragraph 2 explains the definition zakat as "Zakat is a property that must be issued by a Muslim or business entity to be given to those who have the right to receive it in accordance with Islamic law".

The collected zakat is to be distributed to the eight categories of zakat recipients (mustahiq) as clearly stated in the Quran: the poor, the needy, the zakat administrators, the new converts to Islam, the slaves, the debtors, the people fighting for the Allah's cause, and finally the wayfarers. In its development, these eight asnaf can be adapted to the conditions of the community. The eight asnaf zakat arestated in the Quran Surah al-Tawbah verse 60.

"Zakah expenditures are only for the poor and for the needy and for those

\footnotetext{
${ }^{18}$ Moh Abdur Rohman Wahid "Integrasi Pajak dan Zakat di Indonesia”..., 42.
} 
employed to collect [zakah] and for bringing hearts together [for Islam] and for freeing captives [or slaves] and for those in debt and for the cause of Allah and for the [stranded] traveler - an obligation [imposed] by Allah. And Allah is Knowing and Wise"[QS 60 :9].

The purpose of zakat utilization is basically anything that can provide and perpetuate the benefit of the whole community, including efforts that lead to benefit. It can be part of the utilization of zakat when it is viewed from the side of maqasid al-shari ah (sharia purpose). Zakat is a mäliyah ijtimāiyyah worship which has a very important, strategic and decisive position for the development of the people welfare. This zakat provides the fundamental base for the growth and development of the socio-economic power of the people. The teaching content of zakat has broad and complex dimensions, not only the values of spiritual moral worship, and ukhrawi, but also the economic and worldly values. ${ }^{19}$

Zakat can explained under the tawhid-based epistemology. ${ }^{20}$ This epistemology discusses zakat according to the two assertions. First, zakat constitutes an economic and act of worship ${ }^{21}$. Second, zakat represents an act of discharging responsibility as Allah's khalifah on earth (QS, 9: 103). ${ }^{22}$ As an act of worship, zakat involves physical worship through wealth and non-physical worship. This is what distinguishes zakat from other ritual worship. Zakat is a form of worship that is useful not only for the givers, but for other people who need a helping hand (the recipients). Allah obliges every Muslim whose wealth reaches the value of nishab to pay zakat to know how much love the servant has to the Creator more

${ }^{19}$ Moh Abdur Rohman Wahid "Integrasi Pajak dan Zakat di Indonesia”..., 31.

20 Hairul Suhaimi Nahar, "Exploring Stakeholders' View on a Corporatized Zakat Institution's Management Performance”, International Journal of Ethics and Systems, Volume 34, Issue 4 (2018), 611.

${ }^{21}$ Isnawati Rais, "Muzakki dan Kriterianya dalam Tinjauan Fikih Zakat", Al-Iqtishad: Jurnal Ilmu Ekonomi Syariah (Journal of Islamic Economics). Volume 1, Number 1 (2009), 92.

${ }^{22}$ Hairul Suhaimi Nahar, "Exploring Stakeholders' View”..., 611. 
than his wealth.

Zakat becomes mandatory to a person who meets the following six conditions. ${ }^{23}$ The first is Islam. It is an obligatory for a Muslim to pay zakat but not for a non- believer/non-Muslim. The second is Independent. Zakat is an obligation to an independent person and not to slaves. The third is full ownership. A muslim is required to pay zakat only if he/ she has full legal ownership of an asset. The fourth is asset intended to increase wealth. Zakat is levied on an asset that is deliberately possessed to increase the wealth or potentially generated the wealth of its owner. The fifth is completion of hawl. The word hawl means a period of possessing a zakatable asset for at least one Islamic or Hijriyah year. Therefore, zakat is not obligatory if the assets hold is less than a year. The sixth is completion of nishab. Nishab is the minimum value required before an asset is subject to zakat. Any assets or wealth below the minimum value is exempted from zakat. Most ulama recommend to use gold as the basis for the calculation of nishab.

Zakat has a special place in social life in addition to other Islamic financial instruments such as infaq, shadaqah, and waqf. ${ }^{24}$ Zakat has become an important Islamic fiscal tool to address the social injustices which need rectification as well as compensation for the needy. ${ }^{25}$ Zakat indicates that a person in Islam can continue to enjoy the rights of possession and disposal of wealth in a legitimate manner only after a set portion of it has been duly transferred to its rightful owners. ${ }^{26}$ The

\footnotetext{
${ }^{23}$ Mohd Zulkhairi Mustapha and Noor Sharoja Sapiei, "A Comparative Analysis on Zakah and Conventional Taxation”, Jurnal Syariah, Volume 13, Number 1 (2005), 73.

${ }^{24}$ Dian Masyita, "Lessons Learned of Zakah Management"..., 443.

${ }^{25}$ M Ashraf Al Haq and Norazlina binti Abd. Wahab, "Effective Zakah Distribution: Highlighting Few Issues and Gaps in Kedah, Malaysia, Al-Iqtishad: Jurnal Ilmu Ekonomi Syariah, Vol. 9, Number 2 (July 2017), 260.

${ }^{26}$ Konstantinos Retsikas, "Reconceptualising Zakat in Indonesia", Indonesia and the Malay World, Volume 42 (2014),351.
} 
effectiveness of zakat funds could show how zakat could be a catalyst to improve the lives of the poor and the needy. ${ }^{27}$ Zakat is a form of social security in Islam. The rich Muslim sets aside a proportion of their possession for those in needs. The purposes of paying zakat are to create a society based on mutual assistance and guarantee a minimum level of living in the society. ${ }^{28}$

Zakat has a direct impact on the economy and the society. ${ }^{29}$ The wealth collected by zakat could be regarded as productive asset to echance the economy. ${ }^{30}$ Therefore, it is not debatable that the role of zakat on ibadah and social obligation to the poor is very important. ${ }^{31}$ Zakat has been proven to be an effective way to help the poor to liberate them of severe poverty. ${ }^{32}$ The important role and effectiveness of zakat to alleviate poverty is evident during the early history of Islam ${ }^{33}$. Besides, zakat is also able to increase the equity financing by reducing the use of leverage from the corporate perspective. ${ }^{34}$

In order to optimize the impact of zakat in the poverty alleviate programs, we have to categorize the productive poor group into four.

27 Chams-Eddine Djaghballou, Mohamed Djaghballou, Mousa Larbani, and Azhar Mohamad, "Efficiency and Productivity Performance of Zakat Funds in Algeria", International Journal of Islamic Middle Eastern Finance and Management, Volume 11, Issue 3 (2018), 374.

${ }^{28}$ Mohd Zulkhairi Mustapha and Noor Sharoja Sapiei, "A Comparative Analysis on Zakah”..., 75.

${ }^{29}$ Kumara Adji Kusuma and Muhamad Nafik Hadi Ryandono: 275.

${ }^{30}$ Chams-Eddine Djaghballou, Mohamed Djaghballou, Mousa Larbani, and Azhar Mohamad, "Efficiency and Productivity"..., 375.

${ }^{31}$ Abdulah Al-Mamun and Ahasanul Haque: 123.

${ }^{32}$ Naziruddin Abdullah, Alias Mat Derus, and Husam-Aldin Nizar Al-Malkawi, "The Effectiveness of Zakat in Alleviating Poverty and Inequalities", Humanomics, Volume 31, Issue 3 (2015), 324.

33 Rahmatina A Kasri, "Effectiveness of Zakah Targeting in Alleviating Poverty in Indonesia”, Volume 8, Number 2 (July 2016), 170.

${ }^{34}$ Nur Azura B. T. Sanusi, "The Dynamics of Capital Structure in The Presence of Zakat and Corporate Tax", International Journal of Islamic and Middle Eastern Finance and Management, Volume 7, Issue 1 (2014), 107. 
The first category involves the poor who do not have the ability to work because of permanent factor which prevent them from working. The second category consists of the poor who cannot work because of temporary incapabilities. The third category is for those who do not make a living because they do not have the skills or competency to run a business which can generate income (lack of life skills). The fourth category includes people who cannot make a living because they do not have the capital to run a business which can generate income (lack of (apital) $)^{35}$.

Based the categorization of the productive poor group above, there are two models of the distribution of zakat to mustahiq. The first is the distribution of consumptive zakat to complete the basic needs of mustahiq. This action was taken because the mustahiq cannot fulfill their daily needs (categories 1 and 2). The second is the distribution of productive zakat in which zakat is distributed to empower the poor. Therefore, they can improve their standard of living (categories 3 and 4). ${ }^{36}$ For this model, zakat is distributed through life skills training and revolving fund.

Zakat as a social instrument system in Islam has some limitations, among others: (i) marginalizing of non-muslims, (ii) the scope of zakat beneficiaries, (iii) the progressivity of zakat, (iv) the adoption of zakat system, and (v) allowing donors to choose their beneficiaries. ${ }^{37}$

Turning to the dialectical cycle, there are three important stages in paying zakat, namely awareness, knowledge and application. To date, the

\footnotetext{
${ }^{35}$ Hafas Furqani, Ratna Mulyany and Fahmi Yunus, "Zakat for Economic Empowerment of The Poor in Indonesia: Models and Implications", Iqtishadia: Jurnal Kajian Ekonomi dan Bisnis Islam, Volume 11, Number 2 (2018), 395.

${ }^{36}$ Hafas Furqani, Ratna Mulyany and Fahmi Yunus: 392

${ }^{37}$ Fatima Al Matar, "Zakat vs Taxation: The Issue of Social Justice and Redistribution of Wealth", European Journal of Business, Economics, and Accountancy, Volume 3, Number 3 (2015), 121-122
} 
position of zakat in Indonesia is still at the stage of partial awareness This means that from the ritual dimension, zakat has already taken part in many roles. However, from the socio-economic dimension (productive management) zakat does not have many roles especially in any efforts to improve the people welfare. The pattern of zakat handling must also be changed. To date, zakat handling hasonly been approached with the platform of religious law, then in the future, it should be carried out on the basis of financial management instruments and economic policy. ${ }^{38}$

The Indonesian government has regulated the zakat institution. The zakat institutions in Indonesia were formed firstly in the last few years of New Order Rezime (1966-1998) and became truly active during the reformation period (1998-presents). ${ }^{39}$ This regulation about zakat is strengthened by the enhancement of The Zakat Act either The Act No. 38/1999 nor The Act No. 23/2011.

\section{Zakat and tax in Islam}

Tax can be defined as a citizen contribution to state treasury under the law (it can be enforced) and it does not take any benefit directly. Tax is collected under the legal norms in order to cover the production and collective service to reach general wealth ${ }^{40}$. Taxation is a compulsory payment to a government based on possessions of a tax base. The purpose of imposing tax is to raise the government fund for financing the administration of the country. ${ }^{41}$

The application of taxes has risen two contradictory opinions from the scholars. The first is an opinion that some scholars have forbidden taxes.

\footnotetext{
${ }^{38}$ Moh Abdur Rohman Wahid "Integrasi Pajak dan Zakat di Indonesia”..., 38

${ }^{39}$ Konstantinos Retsikas, "Reconceptualizing Zakat..., 341.

${ }^{40}$ Indra Pahala, "Zakat is more Significant..., 287.

${ }^{41}$ Abdulah Al-Mamun and Ahasanul Haque, "Tax Deduction Through Zakat: An Empirical Investigation on Muslim in Malaysia”, Share, Volume 4, Number 2 (July-December 2015), 108.
} 
The second one is that the number of scholars has justified taxes. The scholars who allow taxes for Muslims follow the principle of maslahah. ${ }^{42}$ On the other hand, scholars who allow taxation emphasize a fair taxation system which is in harmony with the spirit of Islam. They argue that a fair taxation system should meet three criteria. First, taxes are imposed to finance expenditures that are really needed to realize maqashid sharia. Second, the tax burden must not be too rigid, but should consider the people ability to bear and be distributed equally to all those who can afford to pay. Third, the collected tax funds are spent honestly for the purpose for which tax is required. ${ }^{43}$

Historically, the government of the Islamic state collected zakat to be an obligation for every rich Muslim. On the other hand, there is also a tax that must be fulfilled by the Muslim as a citizen. Zakat has a lot of differences with conventional tax at the general level. ${ }^{44}$ Basically, zakat cannot be equated with the taxes because both of them have a different legal basis. ${ }^{45}$ Zakat can meet the demands of taxes, but taxes cannot meet the demands of zakat. Zakat and taxes are something different and cannot be put together. The provisions of zakat will continue to apply equally wherever they are. As for taxes, each country will have different tax provisions.

Zakat cannot be fulfilled by taxes. The Ulama have confirmed that the burden among the Muslims for having to pay obth zakat and taxes is the result of the dualism of zakat and taxes. However, this dualism is in accordance with sharia provisions and will guarantee the sustainability of these obligations and perpetuate relations among Muslims through

${ }^{42}$ Moh Abdur Rohman Wahid, "Integrasi Pajak dan Zakat di Indonesia”..., 43-44.

${ }^{43}$ Umer Chapra, Islam dan Tantangan Ekonomi, trans. Ikhwan Abidin Basri, Jakarta: Gema Insani Press, 2002, 100.

${ }^{44}$ Mohd Zulkhairi Mustapha and Noor Sharoja Sapiei, A Comparative Analysis..., 79.

${ }^{45}$ Indra Pahala, "Zakat is more Significant..., 294. 
zakat. Therefore,zakat cannot be removed and renamed by tax, and tax cannot be eliminated. Indonesian Ulama Council (MUI) has maintained the obligation to pay taxes and zakat for Muslims in Indonesia for two reasons. First, zakat is an obligation that must be fulfilled by every Muslim on the basis of the texts of the Quran as well as the Sunnah. Whereas tax is an obligation which must be fulfilled on the basis of government provisions. This has been justified by Islamic teachings based on the principles of general benefit. Zakat is a religious obligation, while taxes are an obligation as citizens in a country. Hence, Muslims are obliged to fulfill zakat to be the realization of religious orders, while mandatory taxes also pay off as realization of a citizen obedience to the state. For these two reason, The Indonesian Ulema Council argues that zakat and tax payments are two different things, although both are impersonal. As a consequence, zakat and tax payments must be practiced by Muslims as two separate things.

The quite extreme opinions about zakat and tax payments emerged from one of the Muslim scholars, Masdar Farid Mas'udi. He argues that Muslims who have paid taxes are no longer obliged to pay zakat. That is because the tax paid has been intended as zakat. The separation of zakat and tax institutions is a misguided and misleading thing because the concept of zakat is a concept of taxin which zakat as its spirit and tax as its body. Zakat and tax are two obligations that can be put together even though they start from the root of the obligations that conventional scholars differ. Thus, the concept of zakat as a spirit of tax is nothing as it is a concept of spiritualization and transcendentalization of the life of the country itself. In this case, religion is considered as the spirit of the state also as universal spirituality that is inclusive, namely the commitment to universal justice, especially for those who are weak and marginalized. ${ }^{46}$

\footnotetext{
${ }^{46}$ Masdar Farid Mas'udi, Pajak itu Zakat Uang Allah Untuk Kemaslahatan Rakyat, Bandung:
} 
There are several similarities between zakat and tax. First, both zakat and tax are obligatory and binding to every resident who meets the requirements. Second, zakat and tax must be deposited with official institutions. Third, in Islamic government, zakat and tax are managed by the state. Fourth, there is no provision to get compensation for certain material in the world. Fifth, in terms of objectives there are similarities between the two, namely to solve economic problems and alleviate poverty in the community. ${ }^{47}$ Taxes and zakat, when integrated in a clear legal concept and rule is believed to be able to raise the Indonesian economy. ${ }^{48}$

In classical Islamic law three tax collection systems are known. The first, is jizyah or head tax. It is a tax imposed to non-Muslims living in an Islamic government (kafir zimmi) by obeying Islamic government regulations and legislation to protect soul, safety, independence and their basic rights. The second is kharaj, namely land and building tax. The third is al'usyur including trade tax, or customs (import and export $\operatorname{tax})^{49}$

Table 1. The Differences Zakat and Tax ${ }^{50}$

\begin{tabular}{|c|c|c|}
\hline The difference & Zakat & Tax \\
\hline Definition & $\begin{array}{l}\text { Clean, increasing, and } \\
\text { developing }\end{array}$ & $\begin{array}{l}\text { Contribution from citizen } \\
\text { to its country, it can be } \\
\text { imposed by the taxation } \\
\text { law. }\end{array}$ \\
\hline Legal basis & Al-Quran and sunnah & Law taxation \\
\hline \multicolumn{3}{|c|}{$\begin{array}{l}\text { Mizan Media Utama, 2010, } 23 . \\
{ }^{47} \text { Ashar, "Pajak dan Zakat: Suatu Kajian Komparatif", Fenomena, Volume V, Number } 2 \\
\text { (2013), } 182 . \\
{ }^{48} \text { Moh Abdur Rohman Wahid, “Integrasi Pajak dan Zakat di Indonesia”..., } 27 . \\
{ }^{49} \text { Moh Abdur Rohman Wahid, "Integrasi Pajak dan Zakat di Indonesia”..., } 32 . \\
{ }^{50} \text { Indra Pahala, Zakat is more Significant..., 292-293. }\end{array}$} \\
\hline
\end{tabular}




\begin{tabular}{|c|c|c|}
\hline The difference & Zakat & Tax \\
\hline Nishab and rate & $\begin{array}{l}\text { It is determined by Allah } \\
\text { and the characteristics } \\
\text { are absolute }\end{array}$ & $\begin{array}{l}\text { It is determinced by the } \\
\text { state and the characteristics } \\
\text { are fluctuating based on the } \\
\text { balance of state budget. }\end{array}$ \\
\hline Characteristics & $\begin{array}{l}\text { Obligatoriy and } \\
\text { continuity }\end{array}$ & $\begin{array}{l}\text { The obligation based on } \\
\text { the necessities and it can be } \\
\text { removed or changed. }\end{array}$ \\
\hline Subject & Islam & Citizen \\
\hline Receiver & It has eight asnaf & $\begin{array}{l}\text { It is for development and } \\
\text { routine expense. }\end{array}$ \\
\hline $\begin{array}{l}\text { Treasure which are } \\
\text { imposed }\end{array}$ & Productive treasures & All treasures \\
\hline Penalty & $\begin{array}{l}\text { From Allah and Islamic } \\
\text { government }\end{array}$ & From the state \\
\hline Motivation & $\begin{array}{l}\text { Faith and devotion to } \\
\text { Allah, obedience and } \\
\text { fear to the country and } \\
\text { sanctions }\end{array}$ & $\begin{array}{l}\text { Taxation law regulatory } \\
\text { compliance and fear of the } \\
\text { taxation lax sanctions. }\end{array}$ \\
\hline
\end{tabular}

If seen from the aspect, principle, source, target, part, level, principle and purpose, tax indeed have some differences from zakat. However, in some cases a substantial equation can be found between tax and zakat. Both tax and zakat contain elements of coercionmanaged by a particular institution; both does not provide direct rewards to the receivers in real terms; and both have the spirit of building the economy of the people. ${ }^{51}$ Table 1 shows some differences between zakat and tax.

Table 2 shows the comparison between zakat and tax based on characteristics of taxation. ${ }^{52}$ From the six characteristics, only two taxation characteristics are suitable with the concept of zakat.

\footnotetext{
${ }^{51}$ Moh Abdur Rohman Wahid, "Integrasi Pajak dan Zakat di Indonesia”..., 32.

${ }^{52}$ Mohd Zulkhairi Mustapha and Noor Sharoja Sapiei, A Comparative Analysis..., 78.
} 
Table 2. The Comparison Between Zakat and Conventional Taxation ${ }^{53}$

\begin{tabular}{|c|c|}
\hline Characteristics of taxation & Zakat \\
\hline Compulsary payment & $\begin{array}{l}\text { Applicable to zakat. However, differences lie } \\
\text { with regards to: } \\
\text { (i) Obligation of zakat derived from Allah. } \\
\text { (ii) Conditions pertaining to whom zakat is lev- } \\
\text { ied differs from conventional taxation. }\end{array}$ \\
\hline $\begin{array}{l}\text { Money raised for government } \\
\text { purpose }\end{array}$ & $\begin{array}{l}\text { Not applicable to zakat. Zakat is raised to be } \\
\text { distributed among the identical categories of } \\
\text { people, in which government per say is not one } \\
\text { of them. }\end{array}$ \\
\hline $\begin{array}{l}\text { Not constitute payment } \\
\text { for service rendered by the } \\
\text { government }\end{array}$ & $\begin{array}{l}\text { Not applicable to zakat. Zakat has no relationship } \\
\text { with the service provided by the government. }\end{array}$ \\
\hline Not penalties & $\begin{array}{l}\text { Not applicable to zakat. Zakat is not a penalty } \\
\text { but rather than an act of worship that will be } \\
\text { rewarded in the hereafter. }\end{array}$ \\
\hline $\begin{array}{l}\text { The exactions are not } \\
\text { arbitrary }\end{array}$ & $\begin{array}{l}\text { Applicable to zakat. In addition, the zakat rate } \\
\text { is fixed at } 2.5 \% \text { while the tax rates may change } \\
\text { over time. }\end{array}$ \\
\hline $\begin{array}{l}\text { The exaction should not } \\
\text { incontestable }\end{array}$ & $\begin{array}{l}\text { Not applicable to zakat. Muslims are not } \\
\text { encouraged to question the zakatable amount, } \\
\text { as it is an act to please Allah. }\end{array}$ \\
\hline
\end{tabular}

In January 2009, The Indonesian Ulama Council held the 3rd Meeting of the Islamic Scholars (Forum Ijtima Ulama III). One of the results of this meeting suggests that zakat on corporate wealth is mandatory. ${ }^{54}$ Indonesia has practiced zakat as a taxable income deduction since 1999 as in the enactment of the Act No. 38/1999. This regulation is also strengthen by the Act No. 23.2011. In the Act No. 23 of 2011 article 22, it isstated that "zakat paid by Muzakki to BAZNAS or LAZ is deducted

\footnotetext{
${ }^{53}$ Mohd Zulkhairi Mustapha and Noor Sharoja Sapiei: 79

${ }^{54}$ Hilman Latief, "Islamic Philanthropy and the Private Sector in Indonesia", Indonesian Journal of Islam and Muslim Societies, Volume 3, Number 2 (2013), 177-178.
} 
from taxable income". Law no. 17 of 2000 concerning tax on income has stated that zakat may reduce income tax double: reducing taxable income and for certain values it also reduces progressive tariffs. ${ }^{55}$.

The Government Regulation (PP) Number 60 of 2010 about Zakat or Religious Donations which are compulsory and which can be deducted from gross income has also stated that: "Zakat or religious donations that are mandatory, which can be deducted from gross income include: (a) Zakat on income paid by taxpayers of individuals who are Muslims and/or by domestic corporate taxpayers owned by adherents of Islam to amil zakat bodies or amil zakat institutions established or authorized by the Government; or; (b) Mandatory religious donations for taxpayers who are individuals of a religion other than the Islamic religion and/or by a domestic corporate taxpayer owned by followers of a religion other than Islam, recognized in Indonesia, are paid to religious institutions established or authorized by the Government.

The application of zakat as a deduction from taxable income provides relief to the Muslim ummah in paying zakat and taxes. In addition, this policy increases awareness and honesty in the community to pay zakat. ${ }^{56}$ Zakat and income tax payment are equally important to the development of a country and social-economic of a community. ${ }^{57}$ These two instruments must be met by every Muslim, both as a citizen and a good Muslim.

\section{Re-formulation of zakat as tax reduction}

This paper tries to reformulate the zakat system as a deduction from income tax. The existing regulations have allowed zakat as a deduction

${ }^{55}$ M Nur Rianto Al Arif, "Efek Multiplier Zakat..., 56.

${ }^{56}$ Thamrin Logawali, Sitti Aisyah, Kamaruddin, and Nurfiah Anwar, "Peranan Zakat Sebagai Pengurang Penghasilan kena Pajak di Kantor Kementerian Agama Kabupaten Gowa”, Laa Maysir, Volume 5, Number 1 (June 2018), 146.

${ }^{57}$ Puteri Nur Liana, "A Priliminary Study..., 118. 
from taxable income. Many people see the current rules that zakat as a deduction from taxable income actually causes the tax burden. Also, zakat that they have to pay is more than just paying taxes. This article offers a reformulation, where zakat is no longer a deduction from taxable income, but rather as a deduction from income tax.

The existing system which permits zakat as a deducation from taxable income is not effective. The awareness of zakat as a taxable income deduction is still low ${ }^{58}$. This condition may be caused by the complexity involved in tax claims and insignificant benefits when compared to effort and return. ${ }^{59}$ At the applicative level of government regulation, it has not been fully implemented, as a number of factors behind it. First, there is still a debate among scholars related to the integration of zakat and taxes. Second, zakat management tends to be conventional and tends to override accountability and transparency. Third, intensive socialization of government regulations tend to be lacking. Fourth, government regulations have not fully supported the integration of zakat and taxes. ${ }^{60}$

There is a big differences between zakat as a taxable income deduction and zakat as a tax deduction. ${ }^{61}$ If zakat is treated as a deduction from taxable income, there will be a light effect on the final amount paid. However, if the zakat is treated as a tax deduction, it will affect the total final amount for the zakat payer significantly. Zakat will replace a similar object covered by tax, before if zakat has not been applied. Motivation and trust are the factors that affect the preference for tax-deductible zakat. ${ }^{62}$

\footnotetext{
${ }^{58}$ Sri Nurhayati and Dodik Siswantoro, "Factors on Zakat (Tithe) Preference as a Tax Deduction in Aceh, Indonesia”, International Journal of Nusantara Islam, Volume 3, Number 1 (2015), 9.

${ }^{59}$ Sri Nurhayati and Dodik Siswantoro, "Factors on Zakat (Tithe) Preference as a Tax Deduction in Aceh, Indonesia”, International Journal of Nusantara Islam, Volume 3, Number 1 (2015), 1.

${ }^{60}$ Moh Abdur Rohman Wahid, "Integrasi Pajak dan Zakat di Indonesia”..., 38

${ }^{61}$ Sri Nurhayati and Dodik Siswantoro, "Factors on Zakat..., 3-4.

${ }^{62}$ Dodik Siswantoro and S. Nurhayati, "Factors Affecting Concern about Zakat as a Tax
} 
The new treatment of zakat as a tax deduction will attract more people to pay zakat and tax, because there is an establishment of zakat incentive. Zakat as a tax reduction will affect significantly to the aggregate consumption. ${ }^{63}$ Although in general, zakat as a deduction from taxable income has an influence on aggregate consumption, savings and investment; however, the impact is actually smaller if zakat is positioned as a component of income tax deduction. This can be illustrated with simple illustrations using calculations as shown in Table 3.

In Table 3, zakat calculated as a deduction from taxable income and calculated as a deduction from income tax are demonstrated clearly in two columns. The illustration in Table 3 assumes that the annual gross income is 100 million. The amount of non-taxable income is 67.5 million, thus the amount of taxable income is 32.5 million. In the first illustration, it is assumed that someone has paid zakat of 1 million. Thus, zakat can be a deduction from taxable income, so that current taxable income becomes 31.5 million. Because the amount of taxable income is still below 50 million, then the amount of tax charged is $5 \%$. As a result, the amount of tax that must be paid is 1.575 million. Thus, the total tax and zakat paid becomes 2.575 million.

Table 3. Ilustration Zakat as a Tax Reduction

\begin{tabular}{lcc}
\hline & $\begin{array}{c}\text { Zakat as deduction from } \\
\text { taxable income }\end{array}$ & Zakat as tax reduction \\
\hline Gross Income & 1 (1) & $(2)$ \\
Non-taxable income* & $67,500,000,000$ & $100,000,000$ \\
Taxable Income & $32,500,000$ & $67,500,000$ \\
\end{tabular}

Deduction in Indonesia”, International Journal Management Business Research, Volume 2, Issue 4 (2012), 293.

${ }^{63}$ M Nur Rianto Al Arif, "Integrasi Pajak dan Zakat di Indonesia”..., 58 
Zakat as deduction from Zakat as tax reduction taxable income

(1)

Zakat as deduction from $1,000,000$ taxable income

Net taxable income $31,500,000$ $32,500,000$

Tax (5\%) $1,575,000$ $1,625,000$ Zakat as tax deduction $1,000,000$ Net tax 625,000 Total Tax + zakat $2,575,000$ $1,625,000$

*assumption: taxpayers who are married and have two children

In Table 3, column 1 shows that zakat deduction from taxable income does not have a significant impact on the obligation that must be paid. This high payment obligation still makes a small incentives for individual to pay taxes and zakat simultaneously. Many people who view the current rules cause the tax burden and zakat to be paid are more than if they pay taxes or zakat only. This is the reason why zakat as a deduction from taxable income is not well responded by the community.

Different things can be seen in the second illustration, in which new zakat is imposed as a deduction from the tax component after income tax is calculated. If a person's taxable income is 32.5 million, then the amount of income tax that must be paid is 1.625 million. Because the individual has paid zakat of 1 million, the amount of income tax paid is reduced. Thus, the amount of tax to be paid is only 625,000 . This makes the total tax and zakat paid is 1.625 million.

Column 2 in Table 3 demonstrates different things from the one in column 1. Zakat as deduction from income tax will significantly reduce liabilities from muzakki. There is a quite big difference between "zakat as a tax deduction" and "zakat as a taxable income deduction". For "zakat a 
a tax deduction", muzakki only pays similarly with the amount of tax. Yet, if "zakat as a taxable income deduction" applies, it deducts the taxable income, and only decreases the total final amount a little bit.

In the case of zakat as a tax deduction, zakat only deducts the tax received by the government, only if it is part of the local budget and the recipients are the same with if government took as tax. Zakat can replace similar objects that are covered by tax before if zakat has not been applied. However, it would not totally ruin the local economy. Besides, it may attract people to pay taxes as it has the zakat incentive ${ }^{64}$. The higher desire of the community to pay zakat, will directly affect the welfare of the mustahik.

Tax rebate through zakat is a combined system of taxation where Muslim people can get rid of double taxation and be motivated towards paying zakat. ${ }^{65}$ The zakat policy as a tax credit is a strategic step in the effort to explore the potential of zakat, while integrating it more deeply in the national economy. At the very least, there are two basic arguments that strengthen this statement. ${ }^{66}$ First, it is the perspective of state finance. When there is a process of synergy and integration of zakat on fiscal policy, there will be a number of benefits to be gained, namely the expansion of the muzakki base and taxpayers, and help alleviate the burden on the state budget in terms of poverty reduction budgets. On the first benefit, through good coordination between the zakat authorities and the tax authorities, the mandatory identification of zakat (muzakki) and mandatorytax will be wider. Thus, it is expected that tax and zakat income will increase. There is no trade off between tax receipts and zakat.

${ }^{64}$ Sri Nurhayati and Dodik Siswantoro, "Factors on Zakat (Tithe) Preference as a Tax Deduction in Aceh, Indonesia", International Journal of Nusantara Islam, Volume 3, Number 1 (2015), 3.

${ }^{65}$ Abdulah Al-Mamun and Ahasanul Haque, "Tax Deduction..., 123.

${ }^{66}$ Moh. Abdur Rohman Wahid, "Integrasi Pajak dan Zakat di Indonesia”...,53 
The second is the perspective of economic distribution which is from the perspective of economic distribution.

This zakat instrument is believed to be an effective means of economic redistribution, in which it guarantees the flow of wealth from the rich to the poor. Thus, the economic growth with equity which has been heard so far will be realized well in the field. There is a significant difference between zakat and tax in terms of distribution. The distribution of zakat will directly touch the community, and as a consequence the effect will immediately be seen. This is different from taxes, where the impact of collecting and distributing tax impacts does not directly touch the community. Zakat will have a significant multiplier effect on the economy ${ }^{67}$ Economic growth will be boosted even higher. That is because the existence of zakat, will boost consumption and investment. Through the program consumptive zakat distribution, the short-term needs of mustahik will be fulfilled. Whereas through productive zakat programs, mustahik households in the long run will have better economic resilience.The zakat multiplier effect in the economy is in line with the word of God in the Quran al-Baqarah verse 261.

"The parable (the living issued by) those who spend their wealth in the way of Allah is similar to a seed that grows seven grains, in each grain: one hundred seeds. God multiplies (rewards) who he wants. And Almighty Allah (His gift) is Knower".

There will be differences in the aggregate consumption between the economy with zakat and economy without zakat. Zakat funds that are well managed and distributed correctly, have an impact on the economic growth as well as income distribution. Similar to zakat, tax is an order that must be carried out for Muslims in the corridor of community

${ }^{67}$ M. Nur Rianto Al Arif, "Efek Multiplier Zakat terhadap Pendapatan di Provinsi DKI Jakarta”, Al-Iqtishad: Jurnal Ilmu Ekonomi Syariah, Volume 4, Number 1 (January 2012), 51. 
responsibility towards the state and for the benefits of the people. ${ }^{68}$

Tax rebate through zakat is a combined system of taxation in which Muslims can get rid of double taxation and be motivated to pay zakat. In order to increase the perception of Muslim societies regarding the tax rebate (deduction) system, perceptions of Islamic rules over halal-haram aspects have a postal influence. Legal consciousness and knowledge about tax and zakat are also considering positively significant factors to grow perceptions towards the tax rebate system. ${ }^{69}$

Some countries have also imposed zakat as a deduction from income tax. Yordania also has applied the zakat as a tool to reduce tax payments to the country ${ }^{70}$. Other countries have also applied the regulation for tax-deduction of zakat paid. Sudan regulation determines that when estimating the income tax of any person the zakat paid shall be deducted from his property assessed for income tax. Saudi Arabia and Kuwait are also two countries that have fully integrated zakat with income tax. In Kuwait, the Law 46 of 2006 concerns to govern zakat and contribution of public and closed shareholding companies in the state's budget. The law governs both zakat and income tax together. According to Saudi law, all business entities must register with the Department of Zakat and Income Tax under the Ministry of Finance. ${ }^{71}$

Malaysia also gives a tax incentives for individual zakat and tax payers. Therefore, zakat payment attracts full tax rebate. For individual zakat and tax payers, zakat payments attracts full tax rebate. This regulation means for every one ringgit of zakat given to SIRC, the tax payable by the zakat payer is reduced by one ringgit during the year of assessment.

${ }^{68}$ Moh Abdur Rohman Wahid "Integrasi Pajak dan Zakat di Indonesia”...,31

${ }^{69}$ Abdulah Al-Mamun and Ahasanul Haque, "Tax Deduction..., 123

${ }^{70}$ Dian Masyita, "Lesson Learned of Zakah..., 446

${ }^{71}$ Mohammed Obaidullah, "Revisiting Estimation Methods of Business Zakat and Related Tax Incentives", Journal of Islamic Accounting and Business Research, Volume 7, Issue 4 (2016), 356. 
If zakat paid is less than tax payable then the balance must be paid to IRB. However, if zakat paid is more than tax payable then the difference cannot be claimed from IRB. ${ }^{72}$ Most muslim taxpayer pay more zakat compared to the amount which they require to pay. If tax payers pay only the zakat, this will affect the tax revenue and in return it will affect the funding of government expenditures. ${ }^{73}$ Based on practices that have been carried out in several countries, zakat as a deduction from income tax will increase people's motivation to pay zakat and taxes

The government should encourage citizens to have tax numbers because without them, it is impossible to claim zakat as a tax deduction. In addition, many state employees still pay zakat directly to the recipients. Even though there is an autodebit facility to pay zakat from a monthly salary. This means that the respondents assume that it is more effective to pay zakat directly. ${ }^{74}$ The government must be able to integrate well between zakat and tax. ${ }^{75}$ This is an effort to optimize the utilization of zakat and taxes for Indonesia's development.

\section{Conclusion}

This paper is offering the re-formulation of zakat as a tax reduction. The government should change the regulation from "zakat as a taxable income reduction" into "zakat as a tax deduction". This change is expected to be able to increase the number of taxpayers (on the one hand) and also the mandatory amount of zakat (on the other hand). Therefore, if the government has a sincere desire to develop the Islamic economy as well

${ }^{72}$ Mohammed Obaidullah, "Revisiting Estimation Methods of Business Zakat"..., 360.

${ }^{73}$ Puteri Nur Liana, "A Priliminary Study..., 122.

${ }^{74}$ Sri Nurhayati and Dodik Siswantoro, "Factors on Zakat (Tithe) Preference as a Tax Deduction in Aceh, Indonesia", International Journal of Nusantara Islam, Volume 3, Number 1 (2015), 16.

${ }^{75}$ Muhammad Rheza Ramadhan, "Integrasi Pajak dan Zakat di Indonesia”, Islamiconomic: Jurnal Ekonomi Islam, Volume 8, Number 1 (2017), 92. 
as zakat has a fairly broad influence in the economy, then zakat should be placed as a deduction from income tax. If zakat is placed as a deduction from income tax, then there will be a greater influence on the economy, compared to when zakat is only positioned as a deduction from taxable income.

There are several policy recommendations proposed in this study. First, the government should encourage the citizens to have a tax numbers. This tax number is necessary for the zakat claim process as a tax deduction. Second, tax regulation should be adjusted, so it can allow zakat as tax reduction. Third,, government should also intensively announce the tax incentives through zakat. Fourth, the education about the obligation of zakat is a shared responsibility of every stakeholder, including ulama' and the government.

\section{Bibliography}

Abdullah, Naziruddin, Alias Mat Derus, and Husam-Aldin Nizar AlMalkawi, "The Effectiveness of Zakat in Alleviating Poverty and Inequalities”, Humanomics, Volume 31, Issue 3 (2015): 314-329. doi: 10.1108/H-02-2014-0016.

Abdullah, Rose, and Abdurrahman Raden Aji Haqqi, "Zakah for Asnaf Al-Gharimun in Brunei Darussalam: Concepts and Practices", AlIqtishad: Jurnal Ilmu Ekonomi Syariah, Volume 9, Number 2 (July 2017): 243-258.

Al Arif, M. Nur Rianto, "Efek Multiplier Zakat Terhadap Pendapatan di Provinsi DKI Jakarta”, Al-lqtishad: Jurnal Ilmu Ekonomi Syariah, Volume 4, Number 1 (January 2012): 51-66.

Al Arif, M Nur Rianto, "Fungsionalisasi Zakat dan Pajak di Dalam Perekonomian”, Jurnal Ekonomi Islam, Volume 3, Number 1 (April 2013): 35-62.

Al Haq, M Ashraf, and Norazlina binti Abd. Wahab, "Effective Zakah Distribution: Highlighting Few Issue and Gaps in Kedah, Malaysia”, Al-Iqtishad: Jurnal Ilmu Ekonomi Syariah, Volume 9, Number 2 (July 
2017): 259-288.

Al Mamun, Abdullah, and Ahasanul Haque, "Tax Deduction Through Zakat: An Empirical Investigation on Muslim in Malaysia", Share, Volume 4, Number 2 (July-December 2015): 105-132.

Al Matar, Fatima, "Zakat vs Taxation: The Issue of Social Justice and Redistribution of Wealth", European Journal of Business, Economics, and Accountancy, Volume 3, Number 3 (2015): 119-129.

Ashar, "Pajak dan Zakat: Suatu Kajian Komparatif", Fenomena, Volume V, Number 2 (2013): 175-187.

Awang, Rohila and Mohd Zulkifli Mokhtar, "Technical Comparison Between Business Zakat and Tax on Business Income in Malaysia”, Malaysian Accounting Review, Volume 10, Number 2 (2011): 13-25.

Canggih, Clarashinta, Khusnul Fikriyah, and Ach. Yasin, "Potensi dan

Realisasi Dana Zakat di Indonesia”, Al-Uqud: Journal of Islamic Economics, Vol. 1, Number 1 (January 2017): 14-26.

Chapra, Umer. Islam dan Tantangan Ekonomi. Jakarta: Gema Insani Press, (2002).

Djaghballou, Chams-Eddine, Mohame Djaghballou, Mousa Larbani, and Azhar Mohamad, "Efficiency and Productivity Performance of Zakat Funds in Algeria", International Journal of Islamic Middle Eastern Finance and Management, Volume 11, Issue 3 (2018): 474-494.

Furqani, Hafas, Ratna Mulyany and Fahmi Yunus, "Zakat for Economic Empowerment of The Poor in Indonesia: Models and Implications", Iqtishadia: Jurnal Kajian Ekonomi dan Bisnis Islam, Volume 11, Number 2 (2018): 392-411.

Kasri, Rahmatina, "Effectiveness of Zakah Targeting in Alleviating Poverty in Indonesia", Al-Iqtishad: Jurnal Ilmu Ekonomi Syariah, Volume 8, Number 2 (July 2016): 169-186.

Kusuma, Kumara Adji and Muhamad Nafik Hadi Ryandono, "Zakah Index: Islamic Economics' Welfare Measurement", Indonesian Journal of Islam and Muslim Societies, Volume 6, Number 2 (2016): 273-301. doi: 10.18326/ijims.v6i2.273-301.

Latief, Hilman, "Islamic Philanthropy and the Private Sector in Indonesia", Indonesian Journal of Islam and Muslim Societies, Volume 3, Number 2 (2013): 175-201. 
Liana, Puteri Nur, "A Preliminary Study o Norms and Motivations

Towards Zakat and Income Tax Payment by Muslim Tax Payer", International Academic Journal of Accounting and Financial Management, Volume 5, Number 3 (2018): 118-123.

Logawali, Thamrin, Sitti Aisyah, Kamaruddin, and Nurfiah Anwar, "Peranan Zakat Sebagai Pengurang Penghasilan Kena Pajak di Kantor Kementerian Agama Kabupaten Gowa”, Laa Maysir, Volume 5, Number 1 (June 2018): 146-171.

Mas'udi, Masdar Farid. Pajak itu Zakat Uang Allah Untuk Kemaslahatan Rakyat. Bandung: Mizan Media Utama, 2010.

Masyita, Dian, "Lessons Learned of Zakah Management from Different Era and Countries", Al-lqtishad: Jurnal Ilmu Ekonomi Syariah, Volume 10, Number 2 (July 2018): 441-456.

Mustapha, Mohd Zulkhairi, and Noor Sharoja Sapiei, "A Comparative Analysis on Zakah and Conventional Taxation", Jurnal Syariah, Volume 13, Number 1 (2005): 65-79.

Nahar, Hairul Suhaimi, "Exploring Stakeholders' View on a Corporatized Zakat Institution's Management Performance”, Volume 34, Issue 4 (2018): 608-631. doi: 10.1108/IJOES-08-2018-0115.

Nurhayati, Sri and Dodik Siswantoro, "Factors on Zakat (Tithe) Preference as a Tax Deduction in Aceh, Indonesia”, International Journal of Nusantara Islam, Vol 3, Number 1 (2015): 1-20.

Obaidullah, Mohammed, "Revisiting Estimation Methods of Business Zakat and Related Tax Incentives", Journal of Islamic Accounting and Business Research, Volume 7, Issue 4 (2016): 349-364.

Pahala, Indra, "Zakat is More Significant than Tax", Review of Integrative Business and Economic Research, Volume 5, Number 2 (2016): 286-294. Raimi, Lukman, Ashor Patel, and Ismail Adelopo, "Corporate Social Responsibility, Waqf System, and Zakat System as Faith-based Model for Poverty Reduction", World Journal of Entrepreneurship, Management and Sustainaible Development, Volume. 10, Issue 3 (2014): 228-242.

Rais, Isnawati, "Muzakki dan Kriterianya dalam Tinjauan Fikih Zakat", Al-lqtishad: Jurnal Ilmu Ekonomi Syariah, Volume 1, Number 1 (2009): 91-106. 
Ramadhan, Muhammad Rheza, "Integrasi Pajak dan Zakat di Indonesia", Islamiconomic: Jurnal Ekonomi Islam, Volume 8, Number 1 (2017): 77 94.

Retsikas, Konstantinos, "Reconceptualising Zakat in Indonesia", Indonesia and the Malay World, Volume 42 (2014): 337-357.

Ridwan, Murtadho, "Zakat vs Pajak: Studi Perbandingan di Beberapa Negara Muslim”, Ziswaf, Vol. 1, Number 1 (June 2014): 123-144.

Salamah, Siti Umus, "Relasi Zakat dan Pajak: Studi Kasus Badan Amil Zakat Nasional Kabupaten Malang dan Kantor Pelayanan Pajak Pratama Kepanjen Malang", Jurisdictie: Jurnal Hukum dan Syariah, Volume 6, Number 1 (2015): 26-36.

Sanusi, Nur Azura B. T., "The Dynamics of Capital Structure in The Presence of Zakat and Corporate Tax", International Journal of Islamic and Middle Eastern Finance and Management, Volume 7, Issue 1 (2014): 89-111.

Siswantoro, Dodik and S. Nurhayati, "Factors Affecting Concern about Zakat as a Tax Deduction in Indonesia", International Journal Management Business Research, Volume 2, Issue 4 (2012): 293-312.

Sodiman., Mustafa, Hadi, Muhammad, Ahmadi, and La Hadisi, "Potensi dan Efketivitas Pengelolaan Zakat di Kabupaten Konawe Selatan”, Li Falah: Jurnal Studi Ekonomi dan Bisnis Islam, Volume I, No. 2 (December 2016): 54-73.

Wahid, Moh Abdur Rohman, "Integrasi Pajak dan Zakat di Indonesia Perspektif Hukum Islam dan Hukum Positif”, El-Jizya: Jurnal Ekonomi Islam, Volume 4, Number 1 (January-June 2016): 27-58. 